\title{
PENGARUH KETERSEDIAAN MODAL DAN LAHAN TERHADAP PROSES TRANSFORMASI SPASIAL HBE DI KAMPUNG KARANGASEM, SLEMAN
}

\author{
Luluk Rani Puspita ${ }^{1}$, Dwita Hadi Rahmi ${ }^{2}$ \\ 1. Mahasiswa Magister Arsitektur, Fakultas Teknik, Universitas Gadjah Mada \\ Jl.Grafika No 2, Yogyakarta \\ 2. Staf Pengajar Magister Arsitektur, Fakultas Teknik, Universitas Gadjah Mada \\ Jl.Grafika No 2, Yogyakarta \\ Email: luluk.rani.puspita@gmail.com
}

\begin{abstract}
Abstrak
Kampung Karangasem merupakan salah satu Kampung di pinggiran Kota Yogyakarta yang mengalami perkembangan yang sangat cepat sejak dibangunnya Kampus UGM dan UNY. Inisiatif warga untuk menangkap peluang ini menjadikan rumah-rumah di Kampung Karangasem mengalami perubahan spasial dari rumah tinggal menjadi home based enterprises (HBE). Penelitian ini bertujuan untuk mengetahui pengaruh ketersediaan modal dan lahan terhadap proses transformasi spasial $H B E$ di Kampung Karangasem . Penelitian ini menggunakan metode deduktif kualitatif. Pengambilan data dilakukan dengan observasi langsung dan pemetaan. Hasil penelitian ini menunjukkan bahwa ketersediaan modal dan lahan memiliki pengaruh terhadap bentuk strategi yang dilakukan pada proses transformasi rumah tinggal menjadi home based enterprises. Kepemilikan modal yang terbatas berpengaruh terhadap proses transformasi pembagian ruang horizontal, pergantian ruang horizontal, perluasan ruang horizontal dan perluasan ruang vertikal. Sedangkan kepemilikan modal yang cukup mendorong pemilik rumah untuk melakukan strategi transformasi perluasan ruang vertikal. Pengaruh ketersediaan lahan yaitu rumah yang masih memiliki lahan kosong dengan luasan yang cukup akan memilih menggunakan strategi perluasan ruang horizontal (horizontal extending of space), sedangkan strategi perluasan ruang vertikal (vertical extending of space) dipilih jika sudah tidak tersedia lahan kosong.
\end{abstract}

Kata kunci: modal, lahan, transformasi, spasial, home based enterprise.

\begin{abstract}
Title: The Effect of Capital and Land Availability on The Spatial Transformation Process at Kampung Karangasem, Sleman

Kampung Karangasem as one of Kampung located in pheriphery of Yogyakarta has very rapid spatial development since the establishment of UGM and UNY. People's initiatives to seize this opportunity, make spatial change from housing into home based enterprises. This study aims to determine the effect of capital and land availability on the spatial transformation process of HBE at Kampung Karangasem. Method used in this study is deductive-qualitative. Data collective by "participant as observer" and mapping.The result of this study indicate that the availability of capital and land has an influence of strategy in the process of transformation from house into a home-based enterprises. Limited capital ownership influences the transformation process of horizontal sharing of space, horizontal shifting of space, horizontal extending of space and vertical extending of space. If homeowner have enough capital, it will make transformation vertical extending of space. The influence of the availability of land is the house that still have enough land with sufficient area will choose to use the horizontal extending of space strategy, while the vertical extending of space strategy is chosen if there is no available vacant land.
\end{abstract}

Keywords: capital, land, transformation, spatial, home based enterprise. 


\section{Pendahuluan}

Kampung Karangasem merupakan salah satu kampung di area pinggiran Kota Yogyakarta yang memiliki fenomena perubahan rumah yang sangat cepat. Kampung ini telah mengalami perubahan dari yang tadinya berupa lahan pertanian menjadi kawasan permukiman. Perkembangan kampung mulai dirasakan warga sejak dibangunnya Kampus UGM dan UNY. Keberadaan kedua kampus ini telah mendorong para pemilik rumah untuk memanfaatkan area rumah tinggalnya menjadi ruang usaha. Inisiatif warga untuk menangkap peluang ini menjadikan rumah-rumah di Kampung Karangasem mengalami perubahan spasial dari rumah tinggal menjadi home based enterprises (HBE).

Ketersediaan modal dan lahan merupakan salah satu faktor yang turut menunjang keberlangsungan $H B E$. Modal yang cukup untuk membuat ruang usaha seringkali tidak diikuti dengan ketersediaan lahan. Sebaliknya beberapa warga yang memiliki modal kurang justru memiliki lahan kosong yang masih cukup luas. Dengan keterbatasan modal ataupun lahan tersebut ternyata tidak menghalangi warga untuk tetap membuat ruang usaha. Dalam proses transformasi terdapat berbagai strategi adaptasi yang dilakukan untuk menyiasati hal ini. Untuk mengetahui bagaimanakah pengaruh ketersediaan modal dan lahan terhadap proses transformasi $H B E$ di Kampung Karangasem, maka penelitian ini menjadi penting untuk dilakukan.

\section{Kajian Pustaka}

\section{Spasial Rumah Tinggal}

Spasial adalah hal-hal yang berkenaan dengan ruang atau tempat (KBBI/ Kamus Besar Bahasa Indonesia, 2017). Sistem spasial pada suatu rumah tinggal berkaitan dengan denah, mencakup organisasi ruang, orientasi serta hirarki ruang (Habraken, 1988). Aplikasi sistem spasial dalam keterkaitannya dengan man, space and time menurut Manuel Marti Jr. (1981), dapat diklasifikasikan menjadi dua faktor, yakni struktur spasial (organisasi, hirarki, sirkulasi serta teritori ruang) dan nilai spasial (makna, fungsi dan pemanfaatan ruang)

Menurut Turner (1972) terdapat tiga fungsi rumah yaitu security, identity, dan opportunity dimana masyarakat kurang mampu akan lebih mengutamakan fungsi rumah sebagai "opportunity"(penunjang kesempatan) dibandingkan "security" (tingkat keamanan) baru setelah itu fungsi rumah sebagai "identity" (identitas).

\section{Transformasi Spasial Rumah Tinggal}

Transformasi rumah adalah strategi penghidupan yang diadopsi oleh rumah tangga yang terlepas dari regulasi maupun aturannya dimana hal ini banyak terjadi di negara-negara berkembang (Avogo, Wedam, dan Opoku, 2017). Transformasi pada rumah tinggal terjadi karena dipengaruhi oleh berbagai faktor seperti faktor sosial, ekonomi, politik dan budaya (Kotharkar dan Deshpande, 2012). Menurut Avogo et al. (2017) salah satu faktor yang mempengaruhi transformasi: "household asset" dan "household need". 
Home Based Enterprises (HBE)

Home based enterprises pada dasarnya adalah rumah yang berfungsi sebagai rumah tinggal sekaligus generator pendapatan (Strassman, 1986 dan Tipple, 2000). HBE memiliki pengertian serupa dengan beberapa istilah seperti rumah produktif, hybrid housing, dan home base work. Menurut Tipple, Coulson, \& Kellet (2002) home based enterprise identik keberadaannya pada negara-negara berkembang yang merupakan salah satu hal penting dalam menunjang "livelihood" warga negaranya. Dalam proses transformasi $H B E$, terdapat strategi adaptasi yang dilakukan oleh pemilik untuk membuat ruang usaha. Menurut Marsoyo (2012) strategi adaptasi rumah tangga untuk "membangun modal spasial" dalam kasus $H B E$ terdiri dari tiga kategori yaitu: (a) Sharing of Space (pembagian ruang) (b) Extending of Space (perluasan ruang), dan (c) Shifting of Space (pergantian ruang).

\section{Metode Penelitian}

Penelitian ini menggunakan pendekatan deduktif kualitatif. Menurut Ihalauw (2008), pendekatan deduktif adalah telaah teoritis, penalaran, perenungan, dan pengalaman untuk mengukur konsep dan menguji dalil atau teori pada ranah empirik, sedangkan kualitatif adalah penelitian yang bermaksud untuk memahami fenomena (fenomenologis) tentang apa yang dialami oleh subjek penelitian, seperti; perilaku, persepsi, motivasi, tindakan, dan lain-lain secara holistik dan dengan cara deskripsi dalam bentuk kata-kata dan bahasa pada suatu konteks khusus yang alamiah dan dengan memanfaatkan berbagai metode alamiah (Kirk et.al dalam Jailani, 2013).
Dalam penelitian ini penulis melakukan observasi secara langsung atau disebut "participant as observer" untuk lebih dapat memahami fenomena transformasi spasial yang terjadi. Pengambilan data dilakukan dengan wawancara secara mendalam kepada pemilik rumah dan pengurus Kampung Karangasem. Pemetaan awal dilakukan dengan membuat blockplan Kampung Karangasem menggunakan data awal dari google earth. Sedangkan pemetaan rumah dilakukan dengan pengukuran langsung pada rumah-rumah yang menjadi sampel penelitian.

Tabel 1. Sampel penelitian

\begin{tabular}{ccc}
\hline No & Kode & Inisial \\
1 & K1 & Ibu CC \\
2 & K2 & Ibu PAR \\
3 & K3 & Bpk.BBG \\
4 & K4 & Ibu SPR \\
5 & K5 & Bpk.SKD \\
6 & K6 6 Ib PRJ \\
7 & K7 & SR \\
8 & K8 & AN \\
9 & K9 & SGT \\
10 & K10 & NG \\
11 & K11 & PRM \\
12 & K12 & NRT \\
13 & K13 & BGS \\
14 & K14 & SWG \\
15 & K15 & AT \\
16 & K16 & DRM \\
17 & K17 & YNC \\
18 & K18 & DD \\
19 & K19 & ED \\
\hline Sumber & Observai & \\
\hline
\end{tabular}

Sumber : Observasi lapangan, 2018

Dalam penelitian ini, pemilihan sampel menggunakan metode "purpossive sampling”. Menurut Arikunto (2006) teknik purposive sampling adalah teknik mengambil sampel dengan tidak berdasarkan random, daerah atau strata, melainkan berdasarkan atas adanya pertimbangan yang berfokus pada tujuan tertentu. Jumlah 
keseluruhan sampel adalah 19 unit rumah yang telah mengalami perkembangan menjadi Home Based Enterprises. Fokus amatan rumah adalah pada perubahan spasial yang diakibatkan oleh modal dan ketersediaan lahan.

\section{Hasil dan Pembahasan}

\section{Ketersediaan Modal}

Warga di Kampung Karangasem terdiri dari beragam profesi diantaranya PNS, guru, pensiunan, dan wiraswasta. $H B E$ di kampung ini berfungsi sebagai pendapatan utama maupun sampingan. Bagi masyarakat yang kurang mampu $H B E$ menjadi pilihan pekerjaan yang relatif mudah dikarenakan dapat membuka usaha sesuai keahlian yang dimiliki. Sedangkan bagi masyarakat yang mampu, $H B E$ menjadi peluang usaha yang menjanjikan untuk dijadikan pemasukan tambahan atau investasi.

Modal merupakan aset yang dimiliki oleh rumah tangga, dalam pengertian ini modal merupakan dana untuk melakukan perbaikan atau mengembangkan rumah. Pada penelitian ini ketersediaan lahan ditemukan berpengaruh terhadap pemilihan strategi transformasi. Terdapat pemilihan strategi yang berbeda pada pemilik rumah dengan ketersediaan lahan yang berbeda.

Pemilik rumah yang memiliki keterbatasan modal cenderung lebih memilih strategi transformasi secara horizontal dengan pembagian ruang (sharing of space) atau pergantian ruang (shifting of space). Hal ini seperti yang terjadi pada kasus K4 dan
K7. Pada kasus K4, penghasilan yang didapatkan saat ini baru cukup digunakan untuk kebutuhan sehari-hari dan biaya sekolah anak, sehingga belum dapat untuk merenovasi rumah. Kebutuhan ruang usaha dimaksimalkan dengan menggunakan ruangan yang ada. Sebagai dampaknya pemilik rumah melakukan adaptasi ruang dengan pembagian ruang dan pergantian ruang. Pembagian ruang ditemukan pada ruang tamu dan dapur, sedangkan pergantian ruang pada area ruang keluarga.

“...kalau nerima laundry, nyetrika, ngepak, disini (ruang tamu) nanti nyucinya di belakang soalnya nggak cukup ruangnya, kalau pas cuaca cerah jemuran cepet kering, kalau mendung ya jemuran dimasukin di rumah..."

(Ibu SPR, pemilik K4, wawancara tanggal 16 Februari 2018)

Pada kasus K7, Ibu SR merupakan "single mother" sehingga hasil dari berjualan lebih diutamakan untuk keperluan sehari-hari dan biaya sekolah anak. Saat ini Ibu SR belum memiliki dana untuk merenovasi rumahnya sehingga menerima kondisi rumahnya apa adanya dari sejak diwariskan oleh kedua orangtuanya. Rumah warisan ini belum memiliki kamar tidur dikarenakan pembagian rumah berdasarkan luasan tanah. Kebutuhan ruang dilakukan dengan meminjam kamar tidur milik kakaknya. Selain itu, saat ini Ibu SR juga terpaksa melakukan pembagian ruang antara kegiatan hunian dengan usaha pada area dapur dan kamar mandi, meskipun sebenarnya hal ini mengganggu privasinya. 


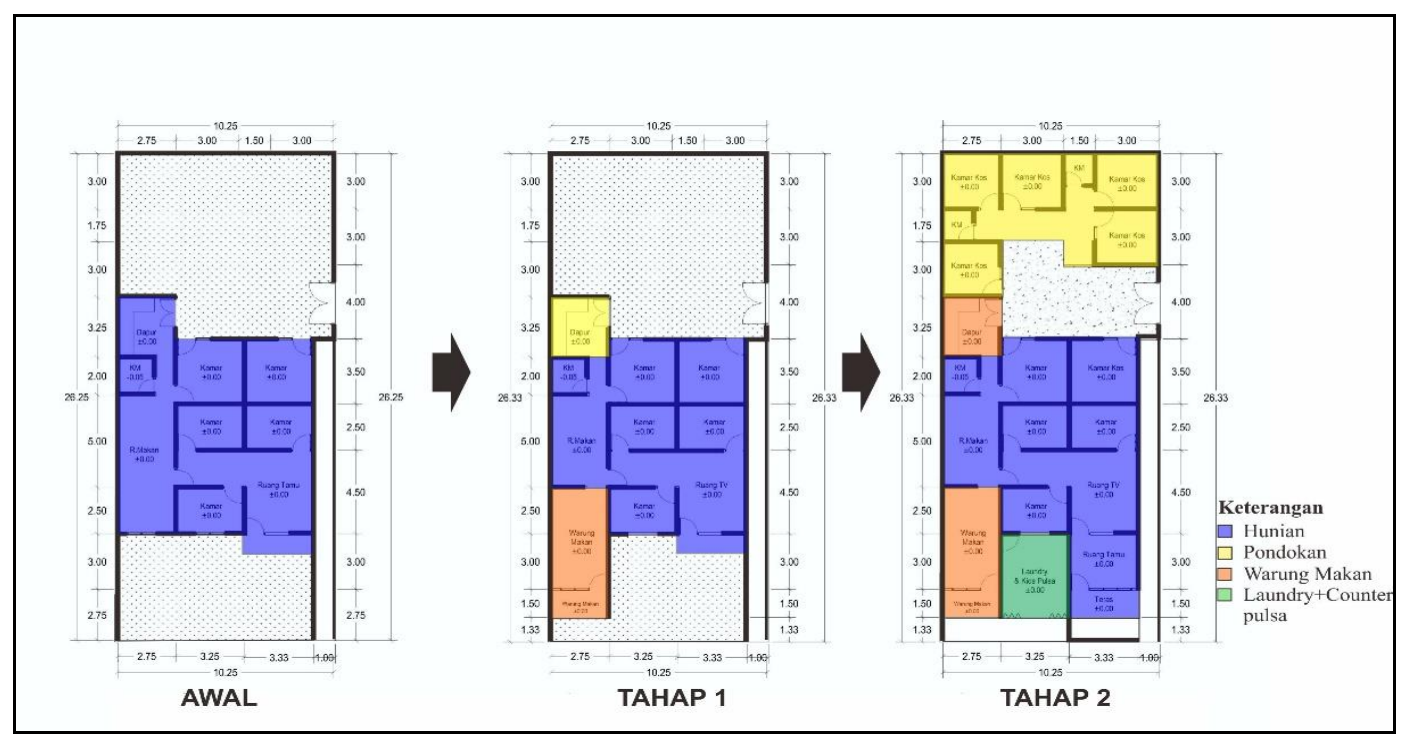

Gambar 1. Proses perluasan ruang horizontal pada K1

Sumber: Analisis penulis, 2018

Pada beberapa kasus ditemukan transformasi dengan perluasan ruang horizontal (horizontal extending of space) secara bertahap seperti pada kasus K1, K9, dan K10. Pada kasus $\mathrm{K} 1$, Ibu $\mathrm{CC}$ mengembangkan rumahnya secara bertahap diawali dengan membangun warung makan di area depan rumah, kemudian membangun pondokan di area belakang rumah.

“...ya sebenarnya ya terganggu kalau pada nunut ke belakang, lewat-lewat ruang keluarga juga, ...kepengennya nanti punya warung yang terpisah biar nggak nglewat-nglewatin..."

(Ibu SR, pemilik K7, wawancara tanggal 15februari 2018)

Pada Kasus K9 Bapak SGT mengembangkan rumahnya setelah mendapatkan penghasilan dari $H B E$ berupa usaha pondokan. Hasil dari usaha ini disisihkan kemudian dipergunakan untuk memperluas ruang pada hunian maupun usahanya secara bertahap. $H B E$ merupakan penghasilan utama dari Bapak SGT, oleh karena itu pengembangan usaha dilakukan semaksimal mungkin untuk mendapatkan hasil yang lebih banyak.

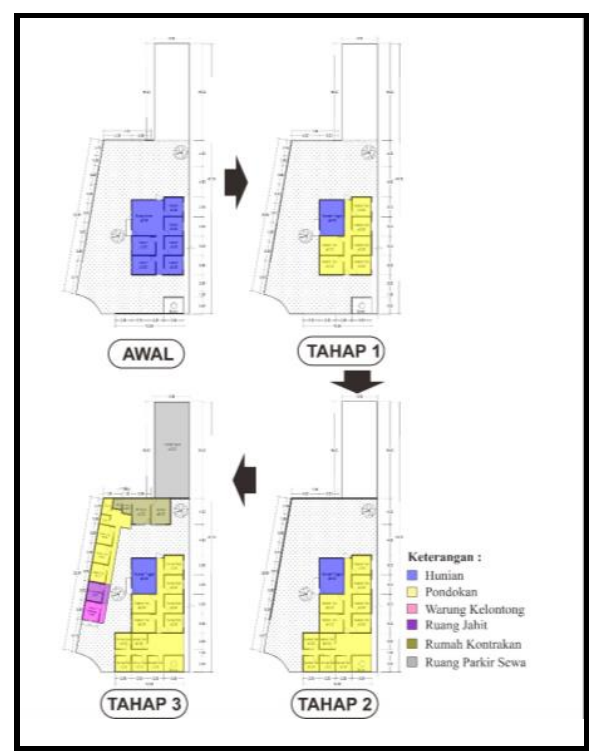

Gambar 2. Proses perluasan ruang horizontal pada $\mathbf{K} 9$

Sumber: Hasil pemetaan, 2018 


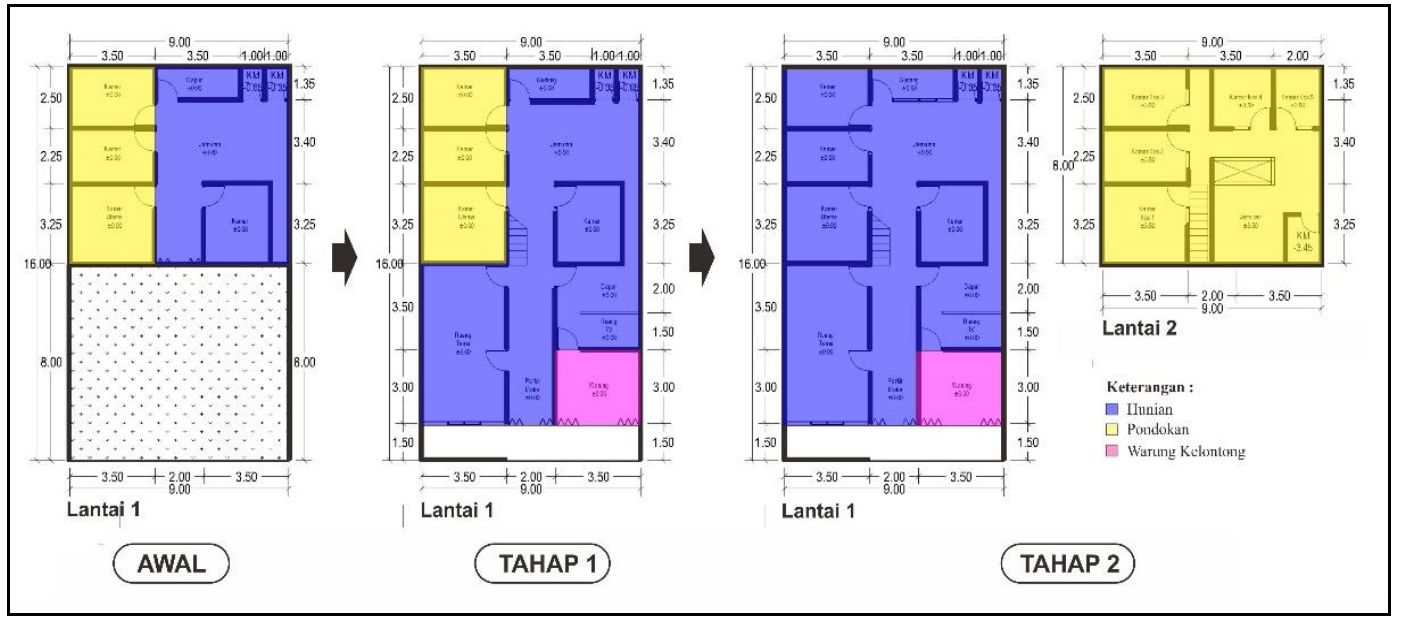

Gambar 3. Proses perluasan ruang horizontal dan vertikal pada K2 Sumber : Analisis penulis, 2018

Perluasan ruang mulai dilakukan pada pengembangan rumah tahap kedua dengan menambah kamar pondokan diarea depan rumah. Jumlah kamar pondokan dari yang tadinya 6 kamar bertambah menjadi 11 kamar. Pada tahap selanjutnya Bpk. SGT membangun bangunan disebelah kiri dan belakang rumahnya untuk difungsikan sebagai warung kelontong, tempat menjahit, kamar pondokan, dapur, kamar mandi, ruang kontrakan, dan ruang parkir sewa.

Pada kasus K2, keterbatasan modal juga berpengaruh terhadap pengembangan rumahnya. Pada awalnya Ibu PAR mendapatkan modal untuk membangun rumahnya dari temannya yang ingin menyewa rumah. Pada saat itu Ibu PAR masih tinggal bersama kakaknya dan area rumah saat ini masih berupa lahan kosong. Dikarenakan modal yang terbatas, rumah pertama yang dibangun hanya setengah dari luasan rumah.

Pengembangan rumah selanjutnya dilakukan dengan menambahkan warung, ruang tamu dan garasi motor pada area depan rumah. Setelah memiliki modal lagi, Ibu PAR membangun lantai dua untuk digunakan sebagai usaha pondokan. Sehubungan dengan modal yang terbatas, maka pembangunan lantai dua baru separuh dari luasan lantai secara keseluruhan.

Pada kasus K10, HBE menjadi solusi bagi Ibu NG yang kehilangan pekerjaannya akibat terkena PHK. Uang pesangon yang didapatkan dipergunakan untuk membangun pondokan dikarenakan Ibu NG merupakan tulang punggung keluarganya. Pada pembangunan tahap awal, Ibu NG baru membangun 6 kamar pondokan. Pengembangan selanjutnya dilakukan secara bertahap setelah mendapatkan penghasilan dari hasil usaha.

“...saya dulu kerja di pabrik kulit di Kotagede, lalu kena PHK, uang pesangon saya gunakan untuk membangun kos-kosan, lalu dibangun lagi bertahap...'

(Ibu NG, pemilik K10, wawancara tanggal 8 februari 2018) 


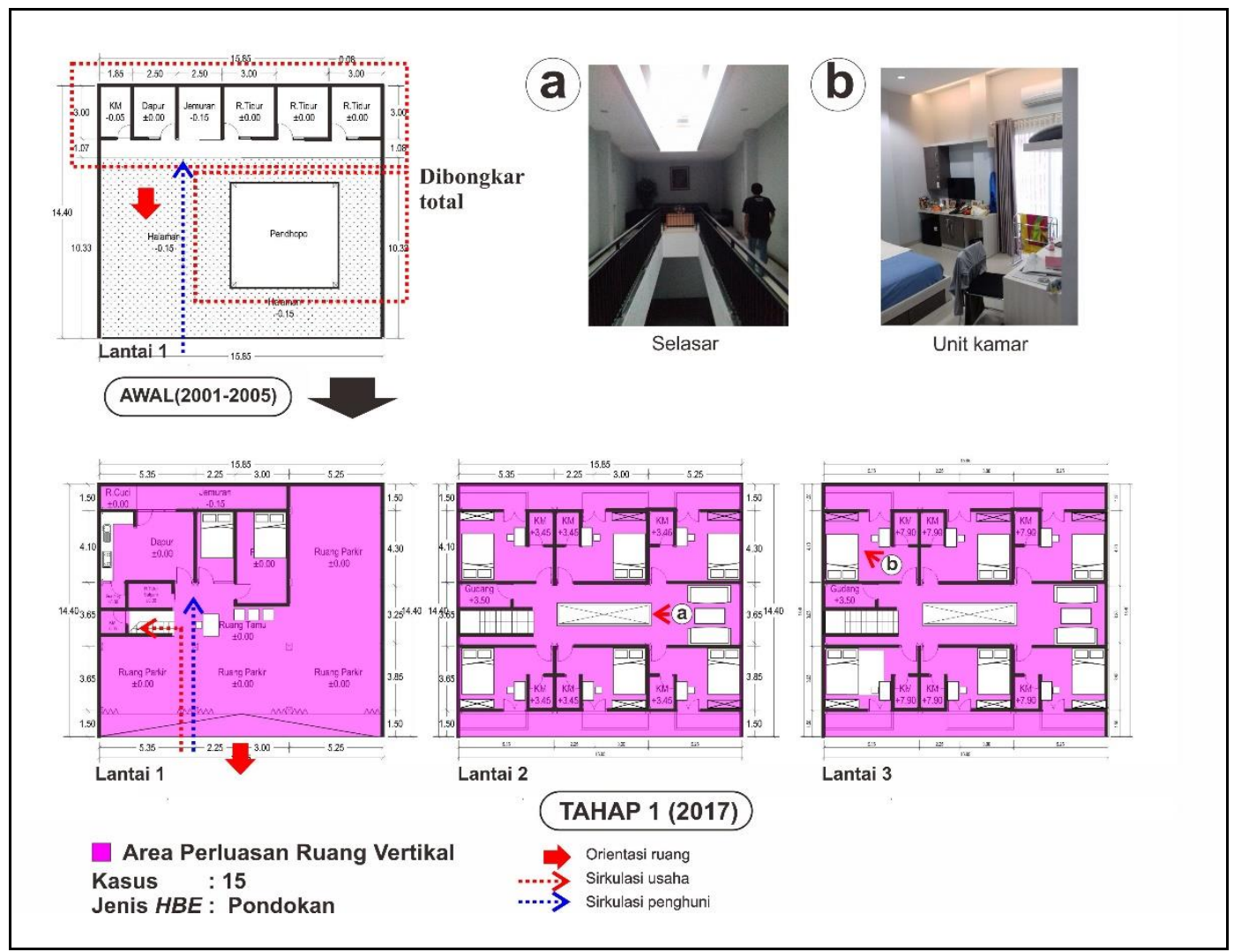

Gambar 4. Proses perluasan ruang vertikal pada K15

Sumber: Analisis penulis, 2018

Pada kasus rumah yang memiliki modal cukup, pengembangan usahanya akan memilih menggunakan strategi perluasan ruang secara maksimal tanpa terkendala modal. Hal ini dapat ditemukan pada kasus K15 dimana modal tidak menjadi masalah sehingga pemilik mengembangkan rumah lama yang dibeli untuk kegiatan usaha dengan membangun 3 lantai sekaligus dengan fasilitas yang lengkap dan mewah.

“...modal untuk membangun ini cash, tidak meminjam bank...bangunan dibuat bagus sekalian biar awet..."

(Bapak AT, pengelola pondokan K15, wawancara tanggal 3 februari 2018)

Dari gambar di atas terlihat bahwa rumah lama yang terdiri dari ruangruang kamar, kamar mandi, dapur dan
${ }^{1}$ pendhopo dibongkar total untuk memaksimalkan ruang usaha pondokan. Pada denah baru fungsi hunian di lantai satu sedangkan lantai dua dan lantai tiga untuk pondokan. Dari perluasan ini diperoleh 12 kamar pondokan dengan ukuran masingmasing unit $5 \times 4$ meter. Selain unit-unit kamar, pada lantai 1 juga dibangun hunian untuk Bapak AT selaku pengelola pondokan.

\section{Ketersediaan Lahan}

Rumah-rumah di Kampung Karangasem memiliki luas lahan yang bervariasi mulai dari $<200 \mathrm{~m}^{2}-$ $>500 \mathrm{~m}^{2}$. Rumah-rumah ini didapatkan melalui proses waris atau jual-beli.

\footnotetext{
1 Pendhopo: Bagian dari rumah Jawa yang berupa bangunan luas, terbuka, dan tanpa sekat yang diletakkan di area depan rumah, digunakan sebagai tempat pertemuan atau perhelatan.
} 


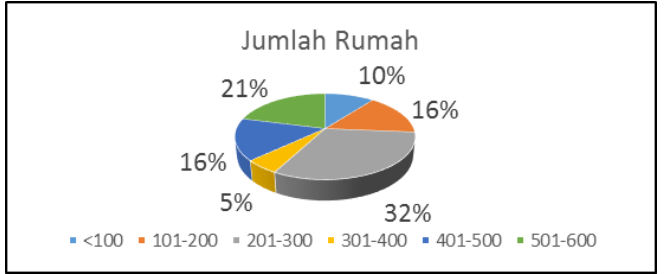

Gambar 5. Prosentase Luas Lahan

Sumber : Analisis penulis, 2018

Dari gambar di atas terlihat bahwa $32 \%$ sampel penelitian memiliki luas lahan 201-300 $\mathrm{m}^{2}$. Sampel rumah dengan luas lahan yang cukup besar yaitu $401-500 \mathrm{~m}^{2}$ dan $501-600 \mathrm{~m}^{2}$ juga banyak ditemukan. Kepemilikan lahan yang besar ini kebanyakan berupa warisan dimana dulu orang tua memiliki lahan berupa kebun atau sawah dengan luasan yang besar.

Beberapa sampel yang memiliki tanah cukup besar juga dipengaruhi oleh harga tanah yang masih murah pada saat membeli lahan. Berdasarkan hasil wawancara salah satu pemilik rumah (pemilik sampel K2), pada tahun 1989 harga tanah di dalam Kampung Karangasem berkisar Rp.30.000,- $/ \mathrm{m}^{2}$, sangat kontras dengan harga tanah pada lahan di dalam kampung saat ini yaitu Rp.3.000.000,- $/ \mathrm{m}^{2}$ (pengelola sampel K15). Harga tanah saat ini pada tepi jalan utama di Kampung Karangasem bahkan mencapai \pm 10 juta-an $/ \mathrm{m}^{2}$. Murahnya harga tanah pada waktu itu dikarenakan kondisi kampung yang belum ramai dan masih berupa sawah atau tegalan, sedangkan kenaikan harga tanah saat ini menunjukkan bahwa Kampung Karangasem sudah sangat berkembang sehingga terjadi peningkatan nilai lahan.

Pada tahap awal pembangunan rumah sebagian kasus telah menghabiskan seluruh lahannya untuk dibangun, sedangkan sisanya masih memiliki lahan kosong. Rumah yang sudah tidak memiliki lahan kosong adalah K4, K6, K7 dan K16 dimana keempat kasus ini hanya memiliki luas lahan $<100-200 \mathrm{~m}^{2}$. Rumah-rumah lainnya yang memiliki luas $>200 \mathrm{~m}^{2}$ rata-rata masih memiliki lahan kosong kecuali kasus K11, K12 dan K18 yang pada tahap pertama pembangunan sudah membangun pada seluruh lahan.

Dalam perkembangannya, rumahrumah mengalami transformasi untuk menyediakan kebutuhan ruang usaha maupun ruang hunian. Terkait dengan penyediaan kebutuhan ruang usaha, ketersediaan lahan kosong tidak mempengaruhi motivasi pemilik rumah untuk menangkap peluang usaha. Pemilik rumah akan berupaya untuk menyiasati keterbatasan lahannya dengan beberapa strategi adaptasi ruang.

Pada sampel kasus yang masih memiliki lahan kosong, pemilik rumah akan mengembangkan rumahnya dengan strategi extending of space dengan menambah ruangan pada area depan, samping kiri, samping kanan, atau belakang rumahnya menyesuaikan dengan kebutuhan. Penambahan ruang ini dapat berlangsung dalam 1 kali tahapan transformasi atau lebih.

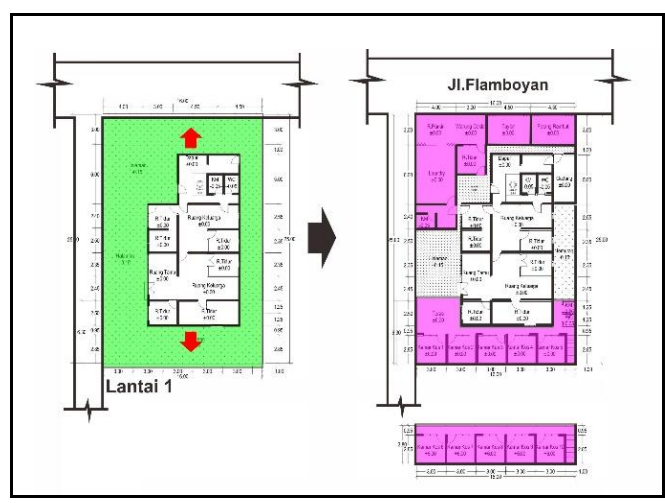

Gambar 6. Pengembangan lahan kosong pada $K 13$

Sumber : Analisis penulis, 2018 
Kasus-kasus yang masih memiliki lahan kosong pada awal pembangunan adalah K1, K2, K3, K5, K9,K10, K13, K14, K15, K17 dan K19. Pada kasus $\mathrm{K} 1 ， \mathrm{~K} 3 ， \mathrm{~K} 9$ ， K10， K13 dan K14 pemilik rumah melakukan transformasi horizontal menggunakan strategi perluasan ruang (horizontal extending of space) dengan cara menambah ruangan secara bertahap menyesuaikan ketersediaan modal.

“...dulu dibelakang itu lahan kosong, lalu dibangun kos-kosan."

(Ibu CC, pemilik K1, wawancara tanggal 17 Maret 2018)

“...ini dari warisan luasnya 500an meter, bangunannya dulu cuma rumah, sisanya tanah kosong, lalu dibangun bertahap."

(Bapak SGT, pemilik K9, wawancara tanggal 27 Maret 2018)

“...ini dulunya kebon, lalu dibangun bertahap...

(Ibu NG, pemilik K10, wawancara tanggal 8 februari 2018)

Pada kasus K2 dan K5 pemilik rumah melakukan transformasi horizontal dengan menambah ruangan kemudian setelah lahan kosong habis, penambahan ruang dilakukan secara vertikal. Pada kasus K15 lahan kosong masih tersedia di awal pembangunan, namun kebutuhan ruang untuk menyediakan kamar pondokan sebanyak 12 kamar tidak dapat dipenuhi dengan luas lahan yang ada sehingga pemilik rumah membongkar bangunan lama dan membuat bangunan 3 lantai.

“...disini dulu rumah lama, ada pendhoponya di depan, rumahnya di belakang, depan rumah kebun ada pohon pisang dan kelapa..."

(Bapak AT, pengelola pondokan K15, wawancara tanggal 3 februari 2018)
Sampel kasus yang sudah tidak memiliki lahan kosong terdapat pada K4, K6, K7, K8, K11, K18 dan K16. Pada kasus K4, K6, K7 dan K16 pemilik rumah sudah tidak memiliki lahan kosong dan memiliki modal yang terbatas sehingga strategi transformasi yang dilakukan adalah pergantian ruang horizontal (shifting of space), pembagian ruang (sharing of space), dan pemampatan ruang (squishing of space). Pada kasus K11 sudah tidak memiliki lahan kosong, Bapak SPR memampatkan ruangan (squishing of space) hunian untuk menambah kamar pondokan.

“...Ini dinding kamar kos saya jebol untuk memperluas ruang laundry..."

(Bapak DD, pemilik K18, wawancara tanggal 16 februari 2018)

Pada K18 lahan yang tersedia di area rumah masih ada namun luasannya tidak besar, pemilik rumah tidak memiliki kendala modal untuk memenuhi kebutuhan ruang laundry, sehingga pemilik hanya melakukan transformasi horizontal dengan memperbesar ruang laundry (horizontal extending of space) dengan mengurangi 1 kamar pondokan.

\section{Pengaruh Modal dan Ketersediaan Lahan terhadap Proses Transformasi Spasial $\mathrm{HBE}$}

Dari pembahasan sebelumnya terlihat bahwa masyarakat berupaya semaksimal mungkin untuk menangkap peluang usaha guna meningkatkan pendapatan keluarganya. Dalam hal ini rumah ternyata bukan lagi sekedar tempat tinggal, melainkan juga sebagai penunjang kesempatan. Hal ini sesuai dengan apa yang telah disampaikan oleh Turner (1972) dimana terdapat tiga fungsi rumah yaitu security, identity dan opportunity dimana 
masyarakat kurang mampu akan lebih mengutamakan fungsi rumah sebagai "opportunity"(penunjang kesempatan) dibandingkan "security" (tingkat keamanan) baru setelah itu fungsi rumah sebagai "identity" (identitas).

Hasil temuan di lapangan memperkaya teori Turner (1972) tersebut, bahwa ternyata dalam perkembangannya fungsi rumah sebagai penunjang kesempatan tidak hanya dijalankan oleh masyarakat kurang mampu, melainkan juga pada masyarakat dengan tingkat perekonomian yang lebih mapan.
Ketersediaan lahan dan ketersediaan modal merupakan variabel-variabel yang diturunkan dari "housing asset" (modal rumah tangga). Modal rumah tangga tersebut mempengaruhi transformasi spasial yang diakibatkan oleh upaya untuk memenuhi kebutuhan ekonomi di dalam rumah, baik sebagai penghasilan utama maupun penghasilan tambahan. Hal ini sesuai dengan teori Avogo et al. (2017), dimana faktor yang mempengaruhi transformasi adalah "household asset" dan "household need".

Tabel 2. Pengaruh ketersediaan modal dan lahan

\begin{tabular}{|c|c|c|c|c|c|c|c|}
\hline \multirow{3}{*}{\multicolumn{2}{|c|}{ No Kode }} & \multicolumn{2}{|c|}{$\begin{array}{l}\text { Pengaruh } \\
\text { Ketersediaan } \\
\text { Modal }\end{array}$} & \multicolumn{2}{|c|}{$\begin{array}{l}\text { Pengaruh } \\
\text { Ketersediaan } \\
\text { Lahan }\end{array}$} & \multirow{3}{*}{ Jenis Transformasi } & \multirow{3}{*}{ Keterangan } \\
\hline & & & & & Besaran & & \\
\hline & & Modal & $\begin{array}{l}\text { Modal } \\
\text { (Rp.,-) }\end{array}$ & Lahan & $\begin{array}{c}\text { Lahan } \\
\text { Kosong } \\
(\mathbf{m} 2)\end{array}$ & & \\
\hline 1 & K1 & $\mathrm{T}$ & $<5 . \mathrm{jt}$ & $\sqrt{ }$ & 141 & $\begin{array}{l}\text { Horizontal } \\
\text { extending of space }\end{array}$ & Tahap 1 \\
\hline \multirow{2}{*}{2} & \multirow{2}{*}{$\mathrm{K} 2$} & $\mathrm{C}$ & $15 \mathrm{jt}$ & $\sqrt{ }$ & 70 & $\begin{array}{l}\text { Horizontal } \\
\text { extending of space }\end{array}$ & Tahap 1 \\
\hline & & $\mathrm{T}$ & $>100 \mathrm{jt}$ & - & 0 & $\begin{array}{l}\text { Vertical } \\
\text { extending of space }\end{array}$ & $\begin{array}{l}\text { Tahap } 2 \text { (lantai } 2 \text { hanya } \\
\text { setengah luasan rumah) }\end{array}$ \\
\hline \multirow{2}{*}{3} & \multirow{2}{*}{ K3 } & $\mathrm{C}$ & $<10 \mathrm{jt}$ & $\sqrt{ }$ & 70 & Sharing of space & $\begin{array}{l}\text { Lahan kosong untuk akses, } \\
\text { tidak memungkinkan } \\
\text { dibangun }\end{array}$ \\
\hline & & $\mathrm{C}$ & $<10 \mathrm{jt}$ & $\sqrt{ }$ & 70 & $\begin{array}{l}\text { Horizontal extending } \\
\text { of space }\end{array}$ & $\begin{array}{l}\text { Ruang usaha dibangun } \\
\text { dengan membongkar kolam } \\
\text { lele }\end{array}$ \\
\hline 4 & K4 & $\mathrm{T}$ & $<5 \mathrm{jt}$ & - & 0 & $\begin{array}{l}\text { Shifting and sharing } \\
\text { of space }\end{array}$ & Tahap 1,2 \\
\hline \multirow{2}{*}{5} & \multirow{2}{*}{ K5 } & \multirow{2}{*}{$\mathrm{C}$} & $>50 \mathrm{jt}$ & $\sqrt{ }$ & 106 & $\begin{array}{l}\text { Horizontal extending } \\
\text { of space }\end{array}$ & Tahap 1 \\
\hline & & & $>100 \mathrm{jt}$ & - & 0 & $\begin{array}{l}\text { Vertical } \\
\text { extending of space }\end{array}$ & Tahap 2 \\
\hline 6 & K6 & $\mathrm{T}$ & $<5 \mathrm{jt}$ & - & 0 & Sharing of space & Tahap 1 \\
\hline 7 & K7 & $\mathrm{T}$ & $<5 \mathrm{jt}$ & - & 0 & Sharing of space & Tahap 1 \\
\hline 8 & K8 & $\mathrm{T}$ & $<10 \mathrm{jt}$ & - & 0 & $\begin{array}{l}\text { Horizontal extending } \\
\text { of space }\end{array}$ & $\begin{array}{l}\text { Tahap } 1 \\
\text { (Menyewa lahan tetangga) }\end{array}$ \\
\hline \multirow{2}{*}{9} & \multirow{2}{*}{ K9 } & $\mathrm{T}$ & $<10 \mathrm{jt}$ & $\sqrt{ }$ & 382 & $\begin{array}{l}\text { Horizontal extending } \\
\text { \&sharing of space }\end{array}$ & Tahap 1 \\
\hline & & $\mathrm{C}$ & $>50 \mathrm{jt}$ & $\sqrt{ }$ & $\begin{array}{l}317 \\
222\end{array}$ & $\begin{array}{l}\text { Horizontal extending } \\
\text { of space }\end{array}$ & $\begin{array}{l}\text { Tahap } 2 \\
\text { Tahap } 3\end{array}$ \\
\hline
\end{tabular}




\begin{tabular}{|c|c|c|c|c|c|c|}
\hline \multirow{3}{*}{$10 \mathrm{~K} 10$} & $\mathrm{C}$ & $<50 \mathrm{jt}$ & $\sqrt{ }$ & 360 & $\begin{array}{l}\text { Horizontal extending } \\
\text { of space }\end{array}$ & Tahap 1 \\
\hline & $\mathrm{T}$ & $<50 \mathrm{jt}$ & $\sqrt{ }$ & 182 & $\begin{array}{l}\text { Horizontal extending } \\
\text { of space }\end{array}$ & Tahap 2 \\
\hline & $\mathrm{T}$ & - & $\sqrt{ }$ & 112 & Squishing of space & Tahap 3 \\
\hline $11 \mathrm{~K} 11$ & $\mathrm{C}$ & $>50 \mathrm{jt}$ & $\sqrt{ }$ & 0 & $\begin{array}{l}\text { Vertical } \\
\text { extending of space }\end{array}$ & Tahap 1 \\
\hline $12 \mathrm{~K} 12$ & $\mathrm{C}$ & $<10 \mathrm{jt}$ & - & - & Squishing of space & Tahap 1 \\
\hline \multirow{2}{*}{$13 \mathrm{~K} 13$} & \multirow{2}{*}{$\mathrm{C}$} & $>50 \mathrm{jt}$ & $\sqrt{ }$ & 258 & $\begin{array}{l}\text { Vertical } \\
\text { extending of space }\end{array}$ & Tahap 1 \\
\hline & & $>50 \mathrm{jt}$ & $\sqrt{ }$ & 141 & $\begin{array}{l}\text { Horizontal extending } \\
\text { of space }\end{array}$ & Tahap 2 \\
\hline \multirow{2}{*}{$14 \mathrm{~K} 14$} & \multirow{2}{*}{$\mathrm{C}$} & $>50 \mathrm{jt}$ & $\sqrt{ }$ & 86 & $\begin{array}{l}\text { Horizontal extending } \\
\text { of space }\end{array}$ & Tahap 1 \\
\hline & & $>50 \mathrm{jt}$ & $\sqrt{ }$ & 86 & $\begin{array}{l}\text { Vertical } \\
\text { extending of space }\end{array}$ & Tahap 2 \\
\hline $15 \mathrm{~K} 15$ & $\mathrm{C}$ & $>300 \mathrm{jt}$ & $\sqrt{ }$ & 228 & $\begin{array}{l}\text { Vertical extending of } \\
\text { space }\end{array}$ & $\begin{array}{l}\text { Tahap } 1 \text { (rumah lama } \\
\text { dirobohkan) }\end{array}$ \\
\hline $16 \mathrm{~K} 16$ & $\mathrm{~T}$ & $>5 \mathrm{jt}$ & - & - & $\begin{array}{l}\text { Horizontal sharing of } \\
\text { space }\end{array}$ & Tahap 1 \\
\hline $17 \mathrm{~K} 17$ & $\mathrm{C}$ & $>50 \mathrm{jt}$ & $\sqrt{ }$ & 89 & $\begin{array}{l}\text { Vertical extending of } \\
\text { space }\end{array}$ & Tahap 1 \\
\hline $18 \mathrm{~K} 18$ & $\mathrm{C}$ & $>25 \mathrm{jt}$ & - & 0 & Squishing of space & Tahap 1 \\
\hline $19 \mathrm{~K} 19$ & $\mathrm{C}$ & $>10 \mathrm{jt}$ & $\sqrt{ }$ & 134 & $\begin{array}{l}\text { Horizontal extending } \\
\text { of space }\end{array}$ & Tahap 1 \\
\hline
\end{tabular}

*C:Cukup, T : Terbatas, Tahap : Tahapan pada saat terjadi transformasi rumah Sumber: Analisis penulis, 2019

Dari tabel di atas dapat terlihat bahwa ketersediaan modal dan lahan memberikan pengaruh pada pemilihan jenis transformasi. Dari 19 sampel penelitian terdapat 13 sampel yang memilih strategi horizontal extending of space yang mana masih memiliki ketersediaan lahan kosong dengan luasan 70-382 $\mathrm{m}^{2}$. Dari 13 sampel ini, 5 diantaranya memiliki modal terbatas dan 8 sisanya memiliki ketersediaan modal. Hal ini berarti bahwa horizontal extending of space dapat terjadi pada sampel dengan modal terbatas maupun cukup namun memiliki ketersediaan lahan meskipun lahan tersebut berasal dari sewa ataupun pembongkaran ruangan lain.

Strategi vertical extending of space ditemukan pada 7 sampel penelitian. Dari 7 sampel tersebut, 6 diantaranya memiliki modal yang cukup, sedangkan 1 sampel sisanya memiliki keterbatasan modal sehingga hanya membangun lantai 2 pada setengah dari total luasan rumah. Hal ini berarti bahwa ketersediaan modal dan lahan berpengaruh terhadap strategi vertical extending of space. Pemilik sampel dengan modal yang cukup akan membangun secara total pada lantai atas rumahnya, sedangkan pemilik sampel dengan modal terbatas tidak ingin melewatkan peluang usaha sehingga membangun secara bertahap.

Strategi sharing of space ditemukan pada 4 sampel penelitian dimana 3 diantaranya merupakan sampel dengan modal terbatas dan 1 sisanya memiliki kecukupan modal. Sampel yang memiliki kecukupan modal memilih menggunakan strategi ini dikarenakan lahan kosong di depan rumahnya merupakan akses untuk masuk ke dalam rumah. Posisi rumah ini berada di dalam komplek pekarangan keluarga 
sehingga tidak berhadapan langsung dengan jalan.

Strategi shifting of space hanya ditemukan pada sampel K4. Hal ini dikarenakan sampel tidak memiliki ketersediaan lahan dan modal. Strategi squishing of space ditemukan pada 3 sampel rumah dengan 2 sampel memiliki ketersediaan modal namun tidak memiliki lahan kosong dan 1 sampel masih memiliki lahan kosong namun memiliki modal yang terbatas. Hal ini berarti bahwa strategi ini dapat dipengaruhi oleh ketersediaan modal dan lahan.

\section{Kesimpulan}

Ketersediaan modal dan lahan memiliki pengaruh terhadap bentuk strategi yang dilakukan pada proses transformasi rumah tinggal menjadi home based enterprises. Kepemilikan modal yang terbatas berpengaruh terhadap proses transformasi spasial pembagian ruang horizontal (horizontal sharing of space), pergantian ruang horizontal (shifting of space, perluasan ruang horizontal (horizontal extending of space) dan perluasan ruang vertikal (vertical extending of space). Sedangkan kepemilikan modal yang cukup mendorong pemilik rumah untuk melakukan strategi transformasi perluasan ruang vertikal (vertical extending of space).

Ketersediaan lahan berpengaruh terhadap proses transformasi spasial. Rumah yang masih memiliki lahan kosong dengan luasan yang cukup akan memilih menggunakan strategi perluasan ruang horizontal (horizontal extending of space), sedangkan strategi perluasan ruang vertikal (vertical extending of space) dipilih jika sudah tidak tersedia lahan kosong. Pada rumah yang tidak memiliki lahan kosong dan belum memiliki modal untuk melakukan penambahan lantai akan memilih strategi pergantian ruang horizontal (horizontal shifting of space) dan pembagian ruang horizontal (horizontal sharing of space). Pada rumah yang sudah tidak memiliki lahan kosong juga ditemukan pemampatan ruang (squishing of space).

\section{Daftar Pustaka}

Arikunto, S. (2006). Prosedur penelitian: Suatu pendekatan praktik. Jakarta: PT. Rineka Cipta.

Avogo, F. A., Wedam, E. A., \& Opoku, S. M. (2017). Housing transformation and livelihood outcomes in Accra, Ghana. Cities, Vol. 68, August 2017, 92-103.

Habraken, N.J. (1988). Type as social agreement. Seoul: Asian Congress of Architect.

Ihalauw, J. (2008). Konstruksi teori. Jakarta: Grasindo.

Jailani, M. S. (2013). Ragam penelitian qualitative (ethnografi, fenomenologi , grounded theory, dan studi kasus). Edu-Bio, Vol. 4, 41-50.

Kotharkar, R., Deshpande, R. (2012). A comparative study of transformations in traditional house form: The case of Nagpur Region, India. ISVS e-Journal, Vol.2, No.2, March 2012, 17-33.

Marsoyo, A. (2012). Constructing spatial capital: Household adaptation strategies in home-based enterprises in Yogyakarta (Disertasi S3, University of Newcastle upon Tyne, 2012. Tidak dipublikasikan).

Marti, Manuel. (1981). Space operational analysis: A systematic approach to 
spatial analysis and programming.. PDA Publishers Corporation.

Strassman, W.P. (1986). Types of neighbourhood and home-based enterprises: evidences from Lima, Peru. Urban Studies: SAGE Journals, Vol. 23, Issue 6, 485-500.

Tipple, G. (2000). Extending themselves: User-initiated transformations of government-built housing in developing countries. Liverpool: Liverpool University Press.

Tipple, G., Coulson, J., \& Kellet, P. (2002). The effects of home-based enterprises on the residential environment in developing countries. Dalam Romaya, S. \& Rakodi, C. (Ed.), Building sustainable urban settlements: Approaches and case studies in the developing world. London: ITDG Pub., 62-76.

Turner, J. F. C. (1972), Housing as a Verb. Dalam Turner, J. F. C. \& Fichter, R. (Ed.), Freedom to build: Dweller control of the housing process. New York: Macmillan Company. 